\title{
Multilingual education: The role of language ideologies and attitudes
}

This paper overviews issues relating to the role of ideologies and attitudes in multilingual education. It argues that ideologies and attitudes are constituent parts of the language planning process and shape the possibilities for multilingualism in educational programs in complex ways, but most frequently work to constrain the ways that multilingual education is conceptualised and delivered. This consideration of the role of ideologies and attitudes provides a contextualisation of the current volume.

Keywords: multilingual education, ideology, attitudes, language planning

\section{Introduction}

Language planning can work to promote multilingualism or it can work to constrain it. Much of the history to human decision-making about languages has in fact sort to constrain multilingualism and to manage linguistic diversity by establishing a small number of languages, often a single language, as the normal languages of the state, and hence of education. This emphasis in language planning can be seen to emerge in the early days of European nation-state formation, for example in the Edict of Villers-Cotterêts (1539), which established French as the norm of French monarchical government (Boulard, 1999). The ideology that a single unified nation-state required a single language gained particular impetus with the French Revolution, during which the argument for the necessity of a single language for the state made based on two main perspectives (Geeraerts, 2003): one pragmatic - promoting effective communication and access to state institutions and political functions and one symbolic - creating and reinforcing a single, unified identity. Schools have been central institutions for establishing national identity and the conceptualisation of the nation state as monolingual entailed a monolingual conceptualisation of the school, with linguistic diversity framed as a threat to national cohesion. This ideological conception of linguistic diversity as problematic for national unity influence the language planning of many of the 
nation-states that gained independence from former colonial powers following World War Two.

Also following World War Two, a competing ideological framing of linguistic diversity in education emerged, which saw education in the children's home language as being of central importance for their educational success. This ideology was given particular prominence by UNESCO, which in 1953 stated that 'it is axiomatic that the best medium for teaching a child is his [sic] mother tongue' (UNESCO, 1953, p. 11). This argument in favour of multilingualism in education was predicated on an ideological framing of education that focused on human capital development rather than national identity as the core objective of education.

These two ideological positions have come to exist in parallel in contemporary educational discourses around the world and may be simultaneously present in many societies. The result is that in debates about education for speakers of minority languages one ideological framing favours educational responses which limit linguistic diversity while the other favours expanding the languages used in educational settings. One consequence of the parallel existence of such discourses is that in many cases, language planning that works to promote linguistic diversity in education may be constrained by a competing desire to limit and manage that diversity (Liddicoat \& Curnow, 2014).

In addition, to these two central ideologies that relate to the understanding of the linguistic identities of nation-states and the role of education within them, other language ideologies may also influence how languages are planned and used in education. One particularly significant ideology relates to how languages varieties are valued within a society. Where language ideologies exist that devalue a language, for example by representing it as a dialect of another language or as a non-standard form, such languages may not be considered worthy of inclusion in education. For example, the debates around 
Ebonics in the United States have persistently focused on the worth of the variety and its suitability for education and in so doing reflect extra-linguistic value systems relating to the social status of speakers and purity of language (Collins, 1999). Similarly, pidgins and creoles are often excluded from education (Siegel, 2005). In both contexts the varieties involved are considered as deviant forms of languages and education are seen as something that should be removed rather than developed. Winsa $(1998,2000)$ has argued that for Meänkieli, a Finnic variety spoken in Sweden, it has been vital to have it recognised as a language in its own right rather than as a dialect of Finnish in order to find space for the variety in educational settings. Languages may be excluded from education because they are not thought to be suitably adapted to deal with the content of educational programs, reflecting ideologies are that some languages are less suited to the expression of modernity than others. This argument has often been used to exclude vernacular languages from educational settings in preference to exogenous languages, often of colonial origin (Mchombo, 2014; Siegel, 2006).

Language planning work constructs the role and function of languages in multilingual contexts in complex ways and the prevailing ideologies within a society and the attitudes and values they (re)produce are an important part of the context in which language education occurs (Hélot \& Young, 2005; Liddicoat, 2013). Multilingual education programs need to navigate through the complexes of attitudes and ideologies that provide the backdrop against which they are implemented and which work to shape the possibilities for multilingual education within a society. The papers in this volume show how such ideologies and attitudes influence the possibilities for multilingual education in a number of societies. In each case, ideologies of uniformity and ideologies of diversity are in potential conflict in framing debates around education and educational practice. 


\section{Studies of multilingual education: Competing attitudes and ideologies}

The contributions to this volume illustrate the tensions that are played out in different policy contexts in the current era of globalisation and mass migration. They show how, faced with high linguistic diversity, policymakers often fall back on entrenched positions that advocate monolingual education in a standard dominant language. The articles highlight the consequences of policy treatments which take a one-size-fits-all approach and thus effectively deny or consciously ignore ethnolinguistic diversity. As we have noted, discourses that emphasise standard languages have their roots in struggles for recognition and nationhood. The ability to use the dominant standard form of a language is often deemed to be a marker of loyalty and successful integration with the nation-state. In policy terms, this expectation also reflects the assumption that a monolingual medium-of-instruction (MOI) policy will equip students best for local labour markets and provide equal access to opportunity. Testing as a form of language policy is also evident as proficiency in the national standard language is increasingly being stipulated as a requirement for citizenship. Such tests can act as a form of linguistic exclusion and social discrimination by preventing immigrants from attaining secure residency rights and acting as barriers to people who may be illiterate or have low levels of education (see, e.g., Committee on Migration, Refugees and Displaced Persons 2013; Shohamy, 2007).

In Europe, these standard language ideologies conflict with the principle of plurilingualism (defined as an individual's communicative competence in a number of languages over his/her lifetime in accordance with his/her needs), to which Council of Europe policy attaches particular importance. As its policy website states:

\footnotetext{
"Education systems need to ensure the harmonious development of learners' plurilingual competence through a coherent, transversal and integrated approach that takes into account all the languages in learners' plurilingual repertoire and their respective functions. This includes promoting learners' consciousness of their existing repertoires
} 
and potential to develop and adapt those repertoires to changing circumstances." (http://www.coe.int/t/dg4/linguistic/Division_en.asp ).

Tendencies that run counter to European plurilingual principles are particularly evident in the polities discussed in the first trio of articles, which demonstrate the assimilationist bias of formal educational language policy.

Delarue and De Caluwe argue that in Flanders, ideologies of standardisation and ambivalence towards multilingualism have worked against the stated Flemish policy goals of education for all. They show how long-held beliefs about language have shaped the policy treatment of diversity in Flemish schools where the widely used dialectal varieties of Flemish (known as Tussentaal or in-between language) are regarded as sub-standard, while literate proficiency in standard Dutch is highly valued. The authors observe that a double standard of elite bilingualism operates in Flanders, where proficiency in Western European languages is considered to be prestigious while bilingualism in immigrant languages is regarded as deficient and their speakers as socially deprived.

Despite the availability and popularity of foreign languages in school curricula, Dutch is strictly prescribed as the sole MOI in Flanders and all forms of multilingual education (MLE) or immersion schooling are prohibited by law. Non-native speakers are therefore forced to study Dutch as a second language in a monoglossic form of submersion schooling which has very detrimental outcomes for immigrant students.

Love shows how beliefs about standard Italian have dominated policymaking in Italy and have focused on the spread of the standard national language at the expense of all others. The introduction of immigrant language testing punishes linguistic difference, as those who fail to achieve at least a certified A2 level of proficiency in the Common European Framework of Reference for Languages are denied permanent residency and can face 
expulsion from the country. In Love's view, this punitive policy position constitutes a major obstacle to the social inclusion and integration of adult immigrants.

France and Germany have also been traditionally regarded as linguistically homogenous nation-states. In both countries, the formal education systems have played a central role in linguistic unification and the transmission of the national language to all citizens, despite the discourses emanating from the Council of Europe and European Union in favour of plurilingualism. Garcia discusses the tension between the conception of language learning as driven by market forces, serving the needs of the European labour market, and by the desire to promote social cohesion and cultural inclusion. She shows how economistic, utilitarian motivations for language learning have come to predominate over cultural, integrative motivations. Yet, at the same time, as Garcia observes, the valuing of immigrant and minority languages for their cultural value alone hinders their achievement of higher status and recognition in the respective education systems of France and Germany.

Beliefs about the relative value of certain languages influence both policy and practice but such beliefs also influence how certain groups are perceived in society. The two following articles reflect on language planning and the position of linguistic minorities. The first contribution examines attitudes towards the linguistic integration of immigrants to the Basque Autonomous Community (BAC). Valadez, Exteberria and Intxausti describe how language planning for the revitalisation and normalisation (acceptance of the language for normal, everyday use) of Basque co-exists with the rapidly rising number of non Basquespeaking immigrants from both outside the region and from Spain. The authors investigated teachers' expectations of the linguistic integration of immigrant children into the BAC. This policy goal presents a challenge in a situation where these children are expected to acquire Castilian as well as Basque. The authors found that teachers with positive views of Basque revitalisation also had positive attitudes towards immigrant languages and their findings 
showed a strong positive correlation between awareness of bilingual education and the successful integration of newcomers. Efforts to overcome Basque's low status as a dominated language have proved successful in the BAC where there are large, affluent, well-educated and well-resourced communities with the ability to wield economic and political power.

In sharp contrast, hostility to underprivileged and socially marginalised linguistic minorities can have very disruptive effects on integration. Eckert reflects on the failure of language planning for Romani in the Czech Republic where, unlike Basque in the BAC, Romani has no associations with positive social identity. In contrast to Basque, Romani suffers from low vitality and its communities are small and highly dispersed, generally living on or below the poverty line. Romani is a stigmatised language with very low prestige and the Roma people are under intense pressure to assimilate into Czech society. Eckert questions whether the European Union Charter for Regional and Minority Languages can protect minority cultures in a policy climate dominated by standard language ideology. She suggests that aversion to diversity and the dominant ideology of standard Czech serve to entrench the marginalisation of the Roma, a situation that is exacerbated by top-down language planning with which the Roma people have not engaged. The social divisions between the Czechs and the Roma are actively reinforced in the media and exclusionary practices are common.

Standard language ideologies hostile to the teaching of Romani in schools provide continued justification for the exclusion of the Roma and obstructing their full participation in Czech society. Such attitudes, as Eckert points out, are directly opposed to the European 'two plus one' language policy (i.e., being able to use two languages in addition to a first language or mother tongue).

Turning to language policy and planning in the developing world, Willans discusses the effects of globalised language planning discourses in the Pacific nation of Vanuatu. Referring to the notion of finding ideological and implementational space for non-dominant 
languages in education (Alexander, 2003; Chick, 2002; Chimbutane \& Benson, 2012; Hornberger, 2005; Taylor-Leech, 2014), Willans shows how opportunities to open up space for vernacular languages have not been taken up in Vanuatu because policymakers have clung to the dual-medium system of education in either English or French. Willans explains how Vanuatu's dual colonial history has influenced language attitudes and created a seemingly insurmountable ideological barrier to developing MLE, resulting in what she calls dual-submersion schooling in English or French for most ni-Vanuatu. Even though neither language is widely spoken outside the education system, policymakers have ignored the possibility of making space for Bislama and other local languages in the curriculum. Willans suggests that while international agencies use rhetoric that supports multilingualism, they may in reality exert pressures that favour the continued teaching of former colonial languages. Moreover, donor competition and policies that fly in the face of established research supporting the value of early learning in a language the child knows best beg the question of how far national policymakers are complicit in these agendas or forced to mediate between them. In Vanuatu policymakers clearly take a top-down, language-as-problem view of multilingualism.

In contrast, Dorner deals with bottom-up language planning in the metropolitan United States, reporting on a study documenting the development of an elementary immersion school in a predominantly English monolingual city. She shows that when school leaders and parents place value on MLE as a right and resource, it can be successful, even when wider policy discourses are overwhelmingly hostile to bilingual education. The parents in her study not only had aspirations for their children's bilingual academic achievement but also saw bilingualism as supporting their children's wellbeing, as they valued the safe bilingual space that the school provided for their children. Dorner's study also highlights the critical importance of effectively marketing MLE to the local community. 
Tollefson's article addresses the way MLE is treated in the mass media, in particular in newspapers. He considers their role in shaping public opinion on language policy. According to Tollefson, all policy debates represent struggles between actors seeking to gain traction in the policymaking process. However, it is usually the most affluent, socially powerful actors who are able to get the most significant media exposure. This article underscores the points made by other authors in this volume about the active role of the media in promoting high versus low prestige bilingualism, in advocating language testing regimes, in reinforcing social divisions, in covering MLE favourably or unfavourably, in disseminating policy discourses and in providing a platform for the marketing MLE to the local community.

Tollefson examines the ideological framing of MOI policy in the contrasting contexts of Hong Kong and Arizona. He compares the coverage of two controversial issues: the introduction of English as the MOI in Hong Kong and the role of English and Spanish in Arizona. Using narrative framing as an analytical lens, Tollefson shows how the newspapers in his study constructed their themes and positions on MOI in Hong Kong and the USA. While media debates on MLE in Hong Kong do not represent the views of political parties and factions, in the USA the bilingual education debate is politically polarised and takes on ethnic and racial overtones. Tollefson also observes how the media can provide a platform whereby groups with similar goals can establish alliances to influence policy. Moreover, a language group which can mobilise its economic, political and educational capital can use the media to its advantage and alternative discourses may appear in different news media in different languages. It is therefore important to analyse the media resources and the narrative frames that are put to use in the media by the various actors in debates on MLE if we are to understand how language policy is shaped and understood by the public. 
In the final article in this volume, Kaplan traces the role of the English language in the historical emergence of the United States. The publication of Webster's dictionary (1806), helped define an emergent sense of an American identity. Kaplan mentions various literary figures who have helped establish a distinctly American voice and variety. He shows how the legitimation of nation-states in the $19^{\text {th }}$ and early $20^{\text {th }}$ centuries relied heavily on a monolingual ideal. Moving to present-day language debates, Kaplan discusses the differing ideological positions on multilingualism taken by the English-Only and the English-Plus movements and lists the mistaken assumptions behind calls for the early introduction of English to children classified as being of limited English proficiency. As Kaplan asserts, the history of language policy in the USA illustrates the kinds of issue that stand in the way of developing more inclusive and workable policy. While Tollefson uses critical analysis of media discourses and Kaplan takes a historical-analytical approach to language ideology, both authors conclude that public debates about multilingual versus monolingual policies are highly politicised and have very little to do with language. The articles in this volume highlight the ideological tensions in language planning and emphasise the urgent need to develop educational language policies that recognise the language rights of learners from diverse language backgrounds and promote meaningful access to education.

The papers in this volume reveal that attitudes and ideologies do not simply represent the context in which multilingual education takes place but rather are fundamentally implicated in the design, delivery of programs and even the possibility that programs may exist. In different contexts, attitudes and ideologies shape multilingual education in different ways, often constraining possibilities. They therefore play a central role in language planning and in explaining how language policy is implemented in a particular society. 


\section{References}

Alexander, N. (2003). Language education policy, national and sub-national identities in South Africa. Strasbourg: Council of Europe.

Boulard, G. (1999). L'ordonnance de Villers-Cotterêts: le temps de la clarté et la stratégie du temps (1539-1992). Revue Historique, 301(1), 45-100.

Chick, J. (2002). Constructing a multicultural national identity: South African classrooms as sites of struggle between competing discourses. Journal of Multilingual and Multicultural Development,23(6), 462-478.

Chimbutane, F., \& Benson, C. (2012). Expanded spaces for Mozambican languages in primary education: Where bottom-up meets top-down. International Multilingual Research Journal, 6(1), 8-21.

Collins, J. (1999). The ebonics controversy in context: Literacies, subjectivities and language ideologies in the United States. In J. Blommaert (Ed.), Language ideological debates.(pp. 201-233). Berlin Mouton de Gruyter.

Committee on Migration, Refugees and Displaced Persons (2013) Integration tests: Helping or hindering integration? Strasbourg: Council of Europe. Retrieved from http://www.assembly.coe.int/nw/xml/XRef/Xref-XML2HTMLen.asp?fileid=19772\&lang=en.

Council of Europe. (2001). Common European Framework of Reference for Languages: Learning, teaching, Assessment. Cambridge: Cambridge University Press.

Geeraerts, D. (2003). Cultural models of linguistic standardisation. In D. René, F. Roslyn \& M. Pütz (Eds.), Cognitive Models in Language and Thought: Ideology, Metaphors and Meanings. pp. 25-68). Berlin: Mouton de Gruyter.

Hélot, C., \& Young, A. (2005). The notion of diversity in language education: Policy and practice at primary level in France. Language, Culture and Curriculum, 18(3), 242-257.

Hornberger, N. (2005). Opening up and filling implementational and ideological spaces for heritage languages in education. Modern Language Journal, 89(4), 605-608.

Liddicoat, A. J. (2013). Language-in-education policies: The discursive construction of intercultural relations. Bristol, UK: Multilingual Matters.

Liddicoat, A. J., \& Curnow, T. J. (2014). Students' home languages and the struggle for space in the curriculum. International Journal of Multilingualism, 11(3), 273-288.

Mchombo, S. (2014) Language, learning and eductaion for all in Africa. In Z. Babaci-Wilhite (Ed.), Giving space to African voices. (pp. 21-47). Rotterdam: Sense Publishers.

Shohamy, E. (2007). Language tests as language policy tools. Assessment in education: Principles, Policy \& Practice (14), 1, 117-130.

Siegel, J. (2005). Literacy in pidgin and creole languages. Current Issues in Language Planning, 6(2), 143-163. doi: 10.1080/14664200508668278 
Siegel, J. (2006). Language ideologies and the education of speakers of marginalized language varieties: Adopting a critical awareness approach. Linguistics and Education 17, 157174.

Taylor-Leech, K. (2013) Finding space for non-dominant languages in education: language policy and medium of instruction in Timor-Leste 2000-2012, Current Issues in Language Planning, (14)1, 109-126

UNESCO. (1953). The Use of Vernacular Languages in Education. Paris: UNESCO.

Winsa, B. (1998). Language Attitudes and Social Identity. Canberra: Applied Linguistics Association of Australia.

Winsa, B. (2000). Defining an ecological niche: The use of 'dialect' or 'language'. Current Issues in Language Planning, 1(3), 431-434. 